\title{
RESULTS FROM THE ALBANIAN ADULT TOBACCO SURVEY
}

\author{
Hana Ross ${ }^{1}$, Eduard Zaloshnja ${ }^{2}$, David T. Levy ${ }^{2}$, Dhimiter Tole ${ }^{3}$ \\ ${ }^{1}$ International Tobacco Control Research, American Cancer Society, Atlanta, GA, USA \\ ${ }^{2}$ Pacific Institute for Research and Evaluation, Calverton, MD, USA \\ ${ }^{3}$ University of Tirana, Albania
}

\begin{abstract}
SUMMARY
Tobacco use prevalence in Europe is characterized by large disparities, with Western nations reporting smoking rates generally below $25 \%$, while Eastern nations have smoking rates usually above $30 \%$. Albania provides a distressing case study for Eastern Europe in which the exposure to the West after the fall of the communist regime dramatically increased the availability of Western-type cigarettes, while adoption of counterbalancing tobacco control measures lagged far behind.

Results based on the representative Albanian Adult Tobacco Survey (AATS) conducted in 2007 suggest that smoking is a major problem, with a $64 \%$ smoking prevalence among Albanian men. It is becoming an increasingly greater concern among women, whose smoking prevalence more than doubled since 1990, reaching $19 \%$ in 2007 . Young women living in urban areas are particularly susceptible to tobacco use; about one-third of them reported that they smoke. About $85 \%$ of current smokers smoke daily and with very high intensity, which further increases their risk of dying of smoking-attributable diseases. Smoking and secondhand exposure kill about 3,800 Albanians per year, about one-fifth of all deaths in the country. In addition, tobacco use imposes opportunity costs on Albanian households, which spent $\$ 358.6$ million on cigarettes in 2007, or about $6 \%$ of the gross domestic product (GDP).

To reduce the health and economic burden caused by tobacco use, the Albanian government should implement and enforce evidence-based tobacco control policies such increasing cigarette taxes; promoting cessation, particularly via the health care system; and enacting stricter clean indoor air laws.
\end{abstract}

Key words: prevalence of tobacco use, tobacco control policy, Albania

Address for correspondence: H. Ross, International Tobacco Control Research, American Cancer Society, 250 Williams St. NW, Atlanta, GA 30303.E-mail: hana.ross@cancer.org

\section{INTRODUCTION}

Smoking is the single most preventable cause of premature mortality, increasing the risk of lung cancer, emphysema, heart disease, stroke, and other diseases $(1,2)$. While some high-income, Westernized nations have seen remarkable declines in smoking rates, many low- to middle-income non-Westernized nations still have high smoking rates. For example, Canada and Australia have smoking rates of $20 \%$ or less, with slightly lower rates for females than males. Meanwhile, China $(3,4)$ and Vietnam (5) have smoking rates well above $50 \%$ for males.

Within Europe, smoking rates show large disparities. In Western Europe, most nations have smoking rates below 25\%, with Sweden at 16\%. Meanwhile, nations in Eastern Europe generally have smoking rates above $30 \%$. Albania, Armenia, Belarus, Georgia, and the Russian Federation have recorded male smoking rates above $50 \%$ in recent years (6). While recorded female smoking rates are lower in these nations, there are signs of their rapid increase. However, little is known about the smoking prevalence in population subgroups defined by age, sex, education, and urban status.

Albania provides a striking case study for Eastern Europe. Until 1990, the cigarettes sold in Albania were domestically produced and of poor quality. With economic liberalization and the freedom to travel after the fall of communism, Albanians' exposure to the outside world dramatically increased their demand for Westerntype cigarettes. Smoking by women, considered unacceptable until then, soon became a sign of emancipation and a modern approach to life, especially among the younger generations. With the fall of communism, trade was also liberalized and incomes increased, creating a favorable climate for foreign cigarettes to flood the market while being heavily advertised by neighboring Italian, Greek, and Yugoslav TV stations.

These events most likely contributed to a significant shift in the causes of death in Albania over the past decade (7). Cardiovascular disease and cancer have replaced infectious and parasitic diseases as the leading causes of death. Deaths due to cancers and cardiovascular diseases increased by $58 \%$ and $43 \%$ respectively, between 1993 and 2003. Lung cancer deaths account for onefourth of all cancer deaths and are likely to increase in the years to come, given the high incidence of tobacco use.

Smoking prevalence in Albania has been captured by few statistics. The Tobacco Control Country Profiles (8) document a dramatic increase of $56 \%$ in the annual per capita consumption of cigarettes (based on tax paid sales) between 1996 and 2000. Data provided by the Albanian Ministry of Health indicate a fur- 
ther increase in cigarette consumption between 2000 and 2006 by almost $75 \%$, when the average per capita consumption increased from 1,056 to 1,841 per year. On the other hand, the Economic Research Service (ERS) found that per capita consumption of cigarettes was already at 2,150 in 1999 (7).

Survey data confirm the upward trend in cigarette consumption. In $1990,50 \%$ of the male and $7.9 \%$ of the female population aged 25 years and older consumed cigarettes (9). Increased smoking prevalence was recorded 10 years later: $60 \%$ of males and $18 \%$ of females were current smokers in the population aged 15 and above (10). Since those in the 15-24 age group generally have lower smoking rates than those at older ages, a comparison of these surveys may understate the rate of increase. A 2001 survey among 25-year-olds and above undertaken in Tirana, the capital of Albania, obtained lower age standardized smoking rates for males (42.8\%), but higher age standardized smoking rates for females (21.2\%) (9). However, a representative survey of smoking behavior among various population subgroups has not been conducted. In addition, past surveys provide limited information about policy-related issues, such as cigarette prices, physician advice to smokers, exposure to advertising, and secondhand smoke.

In a response to the alarming trends in smoking prevalence, the Albanian government began to embrace tobacco control policies. Starting on May 20, 2007, smoking in public places and the sale of tobacco products to minors under 18 years old was banned in Albania. In addition, billboard tobacco advertisements, ubiquitous until then, were banned. These policies, if well-implemented, are expected to have a negative impact on smoking behavior.

In order to assess the extent of the smoking epidemic in Albania and to establish a baseline for measuring the impact of the newly implemented tobacco control policies, we conducted a detailed population survey focusing solely on tobacco use. It gathered information on smoking behavior by age and gender so as to gauge trends among younger vs. older age groups and among males vs. females. The data are also suitable for the analysis of smoking patterns in urban and rural areas. The new law on smoking, if strictly implemented, will most likely affect urban/suburban areas filled with cafés, bars, restaurants, cigarette vendors, and billboards advertising tobacco products. In comparison, a typical Albanian small town or village has very few, if any, public places, and few billboards advertising tobacco products. The survey further collects information on the use of tobacco products other than cigarettes, quantity smoked, quitting behaviors, cigarettes prices, physician advice, exposure to advertising, and secondhand smoke, to fill in the knowledge gap on these aspects of tobacco use in Albania.

\section{MATERIAL AND METHODS}

\section{Sample}

The Albanian Adult Tobacco Survey (AATS) sampled the population living in private households in Albania. The design of the survey called for a representative sample of 4,000 completed individual face-to-face interviews with adults 18 years old and over. The population was divided into two strata: urban and rural. Within each stratum, the sample for AATS was selected through a two-stage process. In the first stage, the population of each stratum was divided into 36 districts and each district was divided into 400-inhabitant segments, or Primary Sampling Units (PSUs). There were 7,823 PSUs in total, of which 3,518 were from urban areas. Sorting these areas by strata and district, with a systematic sampling, 500 PSUs were chosen, of which 250 were in urban areas. In the second stage, for each PSU, eight households were randomly selected. The overall response rate was $91 \%$. Data collection started on April 21, 2007, and lasted for two weeks when the quota of 4,000 respondents was reached.

\section{Data Collection Instruments}

The questionnaire was designed based on a prototype of the Global Adult Tobacco Survey (GATS) available at the time of the survey. GATS is conducted by the World Health Organization in collaboration with the U.S. Centers for Disease Control and Prevention, and represents a global effort to standardize data collection on the prevalence of adult tobacco use. Our survey instrument consisted of five sections: prevalence, cessation, economics, secondhand smoke, and demographics. In the prevalence section, individuals were first asked if they currently smoke cigarettes daily, less than daily, or not at all. If they smoked less than daily, they reported how many days per week they smoked on a typical week. All smokers provided information on their smoking intensity during a typical smoking day. Non-smokers were asked if they smoked cigarettes in the past, either daily, less than daily, or not at all. Former smokers estimated how long they have abstained from cigarette smoking. In the cessation section, smokers were asked if they had made an attempt to quit in the last year, and if they had been advised by a doctor to quit smoking. In the economics section, smokers reported the brand and price of the cigarette they smoked. Exposure to secondhand smoke and to advertising was assessed in the policy section.

\section{Data Weighting}

The sample was not self-weighted, because the urban population was over-sampled in this survey. The initial basic weight variables were given weighting factors of 440.9470 and 551.8855 in urban and rural areas, respectively, to adjust for the distribution of the population between these two areas. Due to differences between the demographics in the survey and in the 2001 Albanian Census, a calculation of post-stratification weights was necessary (see Table 1, Appendix 1). The final weights were calculated by multiplying the basic and post-stratification weights.

\section{RESULTS}

\section{Smoking Prevalence}

As Table 1 indicates, 34.9\% of Albanian adults (18 years old and over) are regular smokers and $6.5 \%$ are occasional smokers. The prevalence of regular smoking increases with age, from $14.9 \%$ among youth (18-19 years old) to $39.8 \%$ among the elderly (65 years old and over). The highest rate of occasional smokers is found in the 18- to 19- and 20- to 24-year-old groups, $9 \%$ and $11.1 \%$, respectively.

Males have a much higher prevalence rate of regular smoking than females do (58.8\% vs. $11.5 \%)$, but females have a higher rate of occasional smoking as opposed to males (7.4\% vs. $5.6 \%$ ). 
Table 1. Smoking prevalence in \% among Albanian adults - 2007

\begin{tabular}{|c|c|c|c|c|c|c|c|c|c|c|c|c|}
\hline \multirow{2}{*}{$\begin{array}{l}\text { Age and } \\
\text { Gender }\end{array}$} & \multicolumn{4}{|c|}{ Whole country } & \multicolumn{4}{|c|}{ Urban } & \multicolumn{4}{|c|}{ Rural } \\
\hline & $\begin{array}{l}\text { Regular } \\
\text { smokers }\end{array}$ & $\begin{array}{c}\text { Non- } \\
\text { regular } \\
\text { smokers }\end{array}$ & $\begin{array}{l}\text { Former } \\
\text { smokers }\end{array}$ & $\begin{array}{c}\text { Non- } \\
\text { smokers }\end{array}$ & $\begin{array}{l}\text { Regular } \\
\text { smokers }\end{array}$ & $\begin{array}{l}\text { Non- } \\
\text { regular } \\
\text { smokers }\end{array}$ & $\begin{array}{l}\text { Former } \\
\text { smokers }\end{array}$ & $\begin{array}{c}\text { Non- } \\
\text { smokers }\end{array}$ & $\begin{array}{l}\text { Regular } \\
\text { smokers }\end{array}$ & $\begin{array}{l}\text { Non- } \\
\text { regular } \\
\text { smokers }\end{array}$ & $\begin{array}{c}\text { Former } \\
\text { smokers }\end{array}$ & $\begin{array}{c}\text { Non- } \\
\text { smokers }\end{array}$ \\
\hline Total & 34.9 & 6.5 & 6.8 & 51.9 & 36.6 & 8.4 & 8.1 & 46.9 & 33.5 & 5.0 & 5.7 & 55.7 \\
\hline $18-19$ years & 14.2 & 9.0 & 0.5 & 76.3 & 20.0 & 10.8 & 0.0 & 69.2 & 9.9 & 7.6 & 0.8 & 81.7 \\
\hline 20-24 years & 29.1 & 11.1 & 2.5 & 57.3 & 30.2 & 15.0 & 2.0 & 52.9 & 28.1 & 7.3 & 2.9 & 61.7 \\
\hline 25-34 years & 35.4 & 7.5 & 2.9 & 54.1 & 38.2 & 9.0 & 4.0 & 48.8 & 33.3 & 6.5 & 2.1 & 58.1 \\
\hline 35-44 years & 36.0 & 5.3 & 6.7 & 52.0 & 41.9 & 7.2 & 7.3 & 43.6 & 32.3 & 4.1 & 6.3 & 57.3 \\
\hline $45-54$ years & 37.6 & 6.2 & 9.0 & 47.2 & 36.4 & 8.0 & 11.9 & 43.7 & 38.6 & 4.6 & 6.4 & 50.4 \\
\hline 55-64 years & 38.6 & 4.0 & 10.4 & 47.0 & 38.2 & 6.0 & 11.4 & 44.4 & 38.9 & 2.1 & 9.5 & 49.5 \\
\hline over 65 years & 39.8 & 4.0 & 14.6 & 41.6 & 38.3 & 3.7 & 18.8 & 39.2 & 40.8 & 4.2 & 11.8 & 43.2 \\
\hline Male & 58.8 & 5.6 & 10.7 & 24.8 & 58.4 & 6.3 & 12.5 & 22.8 & 59.2 & 5.1 & 9.4 & 26.3 \\
\hline $18-19$ years & 26.9 & 15.6 & 1.0 & 56.6 & 40.0 & 14.5 & 0.0 & 45.5 & 16.4 & 16.4 & 1.8 & 65.5 \\
\hline 20-24 years & 49.3 & 9.8 & 3.0 & 37.8 & 47.6 & 12.1 & 2.4 & 37.9 & 50.9 & 7.9 & 3.5 & 37.7 \\
\hline 25-34 years & 64.2 & 6.7 & 5.3 & 23.8 & 63.3 & 7.3 & 6.2 & 23.2 & 65.0 & 6.2 & 4.5 & 24.3 \\
\hline $35-44$ years & 61.6 & 3.1 & 11.3 & 24.0 & 69.5 & 3.4 & 12.1 & 14.9 & 56.9 & 2.9 & 10.9 & 29.3 \\
\hline $45-54$ years & 63.9 & 4.5 & 14.6 & 16.9 & 62.5 & 4.2 & 19.8 & 13.4 & 65.1 & 4.8 & 10.3 & 19.9 \\
\hline 55-64 years & 59.6 & 4.1 & 17.1 & 19.2 & 51.9 & 5.3 & 20.9 & 21.9 & 66.5 & 3.0 & 13.8 & 16.8 \\
\hline over 65 years & 60.2 & 2.5 & 19.8 & 17.6 & 51.4 & 2.8 & 22.2 & 23.6 & 65.9 & 2.3 & 18.2 & 13.6 \\
\hline Female & 11.5 & 7.4 & 2.9 & 78.2 & 16.3 & 10.3 & 4.0 & 69.4 & 7.7 & 5.0 & 2.1 & 85.3 \\
\hline $18-19$ years & 2.5 & 2.9 & 0.0 & 94.6 & 0.0 & 7.1 & 0.0 & 92.9 & 4.2 & 0.0 & 0.0 & 95.8 \\
\hline 20-24 years & 10.3 & 12.3 & 1.9 & 75.5 & 15.7 & 17.4 & 1.7 & 65.3 & 4.5 & 6.7 & 2.2 & 86.5 \\
\hline 25-34 years & 8.9 & 8.3 & 0.8 & 82.0 & 13.7 & 10.6 & 1.9 & 73.9 & 5.6 & 6.7 & 0.0 & 87.8 \\
\hline $35-44$ years & 10.2 & 7.5 & 2.0 & 80.2 & 16.8 & 10.7 & 3.0 & 69.5 & 5.7 & 5.3 & 1.3 & 87.7 \\
\hline $45-54$ years & 9.5 & 8.0 & 3.1 & 79.5 & 10.9 & 11.7 & 4.3 & 73.2 & 8.1 & 4.3 & 1.9 & 85.6 \\
\hline 55-64 years & 16.4 & 3.9 & 3.3 & 76.4 & 24.5 & 6.6 & 1.9 & 67.0 & 8.2 & 1.2 & 4.7 & 85.9 \\
\hline over 65 years & 21.8 & 5.4 & 10.1 & 62.7 & 27.3 & 4.5 & 15.9 & 52.3 & 18.0 & 6.0 & 6.0 & 70.0 \\
\hline
\end{tabular}

Note: Regular smoker is defined as a daily smoker. Non-regular smoker is defined as a smoker that consumes cigarettes less than daily, but at least once a week. "Nonregular smokers" and "occasional smokers" are being used interchangeably in this paper.

Smoking rates are similar among males in urban and rural areas with the exception of the 18- to 19-year-old group. Forty percent of urban males in this group are regular smokers vs. $16.4 \%$ of rural males, indicating that urban males tend to initiate smoking earlier compared to their rural counterparts. On the other hand, there is a big difference between urban and rural females of all ages with respect to smoking behavior. Women in urban areas smoke much more $-16.3 \%$ of them are regular smokers and $10.3 \%$ are occasional smokers. Only $7.7 \%$ of rural females are regular smokers and only 5\% are occasional smokers. Alarming is the high smoking prevalence among young females $-22.6 \%$ of 20 - to 24-year-old females smoke regularly or occasionally. This statistic is even more profound in the urban areas, where $33.1 \%$ of 20- to 24-year-old females smoke.

The survey detected only a negligible use of other tobacco products. Only two respondents reported smoking a pipe and one respondent smoked cigars.

\section{Quantity Smoked}

The average number of cigarettes smoked per day by a regular smoker is 21.9, and the smoking intensity is highest in the middle age groups (ages 25-54). The smoking intensity is slightly higher in rural areas (22.3 cigarettes per day), and substantially higher among males compared to females (23.5 cigarettes per day vs. 14 cigarettes per day).

The average number of cigarettes smoked in a typical week by occasional smokers is 16.7. Similar to regular smokers, the smoking intensity among occasional smokers is slightly higher among men (an average of 18.6 cigarettes per week) compared to women (15.3 cigarettes per week), but occasional smokers consume on average more cigarettes in urban areas compared to their rural counterparts (17.4 vs. 15.7 cigarettes per day).

\section{Quitting Behaviors}

Only $6.8 \%$ of the population of Albania consists of former smokers, and more of them live in urban compared to rural areas (Table 1). Males are more than 3-times as likely to be former smokers compared to females, with $10.7 \%$ of former smokers among the male sample compared to $2.9 \%$ among the female sample. Among those who had completely quit smoking, $77.2 \%$ 
Table 2. Time since former smokers completely stopped smoking (\% of all former smokers)

\begin{tabular}{|c|c|c|c|c|c|c|c|c|c|}
\hline & \multicolumn{3}{|c|}{ The whole country } & \multicolumn{3}{|c|}{ Urban } & \multicolumn{3}{|c|}{ Rural } \\
\hline & $\begin{array}{l}\text { Less than } 6 \\
\text { months }\end{array}$ & $\begin{array}{c}\text { 6-11 } \\
\text { months }\end{array}$ & $\begin{array}{l}\text { One year } \\
\text { and over }\end{array}$ & $\begin{array}{l}\text { Less than } 6 \\
\text { months }\end{array}$ & $\begin{array}{c}\text { 6-11 } \\
\text { months }\end{array}$ & $\begin{array}{l}\text { One year } \\
\text { and over }\end{array}$ & $\begin{array}{c}\text { Less than } 6 \\
\text { months }\end{array}$ & $\begin{array}{c}6-11 \\
\text { months }\end{array}$ & $\begin{array}{l}\text { One year } \\
\text { and over }\end{array}$ \\
\hline Total & 7.5 & 15.3 & 77.2 & 7.0 & 12.2 & 80.8 & 8.0 & 18.8 & 73.2 \\
\hline $8-19$ years & 0.0 & 0.0 & 100.0 & 0.0 & 0.0 & 0.0 & 0.0 & 0.0 & 100.0 \\
\hline 20-24 years & 31.4 & 50.2 & 18.5 & 54.9 & 45.1 & 0.0 & 15.5 & 53.6 & 30.9 \\
\hline 25-34 years & 9.2 & 38.5 & 52.3 & 7.0 & 21.7 & 71.3 & 12.5 & 62.5 & 25.0 \\
\hline $35-44$ years & 9.1 & 23.6 & 67.3 & 7.5 & 18.3 & 74.2 & 10.4 & 27.5 & 62.1 \\
\hline $45-54$ years & 6.9 & 8.5 & 84.6 & 9.1 & 4.4 & 86.5 & 3.1 & 15.4 & 81.5 \\
\hline 55-64 years & 4.1 & 7.8 & 88.1 & 4.7 & 8.8 & 86.4 & 3.3 & 6.7 & 90.0 \\
\hline over 65 years & 4.4 & 5.2 & 90.4 & 0.0 & 9.9 & 90.1 & 9.2 & 0.0 & 90.8 \\
\hline Male & 9.0 & 12.9 & 78.1 & 8.2 & 7.5 & 84.2 & 9.7 & 18.3 & 72.0 \\
\hline $18-19$ years & 0.0 & 0.0 & 100.0 & 0.0 & 0.0 & 0.0 & 0.0 & 0.0 & 100.0 \\
\hline 20-24 years & 53.1 & 15.6 & 31.3 & 100.0 & 0.0 & 0.0 & 25.0 & 25.0 & 50.0 \\
\hline 25-34 years & 10.7 & 39.3 & 50.0 & 9.1 & 18.2 & 72.7 & 12.5 & 62.5 & 25.0 \\
\hline 35-44 years & 10.7 & 17.8 & 71.5 & 9.5 & 9.5 & 81.0 & 11.5 & 23.1 & 65.4 \\
\hline $45-54$ years & 5.8 & 10.2 & 84.1 & 7.1 & 5.4 & 87.5 & 3.6 & 17.9 & 78.6 \\
\hline 55-64 years & 4.8 & 6.6 & 88.6 & 5.1 & 5.1 & 89.7 & 4.3 & 8.7 & 87.0 \\
\hline over 65 years & 6.9 & 2.8 & 90.3 & 0.0 & 6.3 & 93.8 & 12.5 & 0.0 & 87.5 \\
\hline Female & 2.0 & 24.1 & 73.9 & 3.3 & 26.0 & 70.7 & 0.0 & 21.1 & 78.9 \\
\hline $18-19$ years & 0.0 & 0.0 & 0.0 & 0.0 & 0.0 & 0.0 & 0.0 & 0.0 & 0.0 \\
\hline 20-24 years & 0.0 & 100.0 & 0.0 & 0.0 & 100.0 & 0.0 & 0.0 & 100.0 & 0.0 \\
\hline $25-34$ years & 0.0 & 33.3 & 66.7 & 0.0 & 33.3 & 66.7 & 0.0 & 0.0 & 0.0 \\
\hline 35-44 years & 0.0 & 56.4 & 43.6 & 0.0 & 50.0 & 50.0 & 0.0 & 66.7 & 33.3 \\
\hline $45-54$ years & 12.5 & 0.0 & 87.5 & 18.2 & 0.0 & 81.8 & 0.0 & 0.0 & 100.0 \\
\hline 55-64 years & 0.0 & 14.3 & 85.7 & 0.0 & 50.0 & 50.0 & 0.0 & 0.0 & 100.0 \\
\hline over 65 years & 0.0 & 9.3 & 90.7 & 0.0 & 14.3 & 85.7 & 0.0 & 0.0 & 100.0 \\
\hline
\end{tabular}

were successful in doing so more than one year before the survey, and about $15.3 \%$ of them have quit rather recently -6 to 11 months before the survey (Table 2). The 20- to 24-year-old age group, as expected, had the lowest percentage of long-time quitters.

During the 12 months preceding the survey, only 26.6 percent of regular smokers stopped smoking for 24 hours or longer due to an attempt to quit smoking. This percentage is higher in urban areas (30.9\%) and at both ends of the age spectrum, signaling a higher demand for cessation services among the very young and relatively older smokers.

\section{Physician Visits and Advice}

Less than half of those who saw a doctor during the 12 months preceding the survey received advice from their health care providers to quit smoking. However, $54.2 \%$ of smokers did not see a doctor at all during that period. There is a lower rate of doctor visits in rural areas and among males. Younger smokers were the least likely to receive advice to quit smoking, especially in rural areas.

\section{Smoking Prevalence by Education}

To evaluate the impact of education on smoking behavior, we divided the respondents into three educational categories: low-level (0-8 years of schooling), middle-level (9-12 years of schooling) and high-level (13 years of schooling and more). The highest smoking prevalence is observed among those with the highest education (44.1\% smoking prevalence), but the prevalence among respondents with middle-level education is also high (42.3\% smoking prevalence) (Table 3). The most educated have a larger share of occasional smokers compared to the other two educational categories, with $27 \%$ of smokers in this group who are some day smokers. In addition, the most educated also report the largest percentage of former smokers $-9.6 \%$ of people in this group reported to have quit the habit. The smoking status among the most educated is least affected by rural/urban status.

\section{Exposure to Secondhand Smoke}

About three quarters of the population is exposed to secondhand smoke at home and at work. Since the majority of smokers in households are men, more non-smoking women are exposed to secondhand smoke at home compared to non-smoking men. The exposure to secondhand smoke at work is more frequent among men (since only $38 \%$ of women reported to be working outside the house compared to $64 \%$ of men) and among younger age groups (63\% of those aged 26-60 work outside the house, compared to $10 \%$ of those above age 60 ). Furthermore, exposure to secondhand smoke is very common in government offices, medical facilities 
Table 3. Smoking prevalence by education

\begin{tabular}{|c|c|c|c|c|c|c|c|c|c|c|}
\hline $\begin{array}{c}\text { Years of } \\
\text { education }\end{array}$ & $\begin{array}{c}\text { Regular } \\
\text { smokers }\end{array}$ & $\%$ & $\begin{array}{c}\text { Occasional } \\
\text { smokers }\end{array}$ & $\%$ & $\begin{array}{c}\text { Former } \\
\text { smokers }\end{array}$ & $\%$ & $\begin{array}{c}\text { Non- } \\
\text { smokers }\end{array}$ & $\%$ & Total & $\%$ \\
\hline Whole country & $\mathbf{6 9 3 , 3 1 1}$ & 34.9 & 129,209 & $\mathbf{6 . 5}$ & 134,687 & $\mathbf{6 . 8}$ & $\mathbf{1 , 0 3 1 , 0 0 8}$ & $\mathbf{5 1 . 9}$ & $\mathbf{1 , 9 8 8 , 2 1 5}$ & 100 \\
\hline $0-8$ & 284,091 & 35.4 & 30,634 & 3.8 & 51,419 & 6.4 & 435,779 & 54.3 & 801,923 & 100 \\
\hline $9-12$ & 300,648 & 35.5 & 57,801 & 6.8 & 50,619 & 6.0 & 438,850 & 51.8 & 847,918 & 100 \\
\hline $13+$ & 108,572 & 32.1 & 40,774 & 12.0 & 32,649 & 9.6 & 156,379 & 46.2 & 338,374 & 100 \\
\hline Urban & 319,046 & 36.6 & 73,169 & $\mathbf{8 . 4}$ & $\mathbf{7 0 , 4 7 3}$ & $\mathbf{8 . 1}$ & $\mathbf{4 0 9 , 0 5 1}$ & 46.9 & $\mathbf{8 7 1 , 7 3 9}$ & 100 \\
\hline $0-8$ & 70,331 & 36.8 & 11,416 & 6.0 & 17,555 & 9.2 & 91,698 & 48.0 & 191,000 & 100 \\
\hline $9-12$ & 161,920 & 39.0 & 29,935 & 7.2 & 28,041 & 6.8 & 195,242 & 47.0 & 415,138 & 100 \\
\hline $13+$ & 86,795 & 32.7 & 31,818 & 12.0 & 24,877 & 9.4 & 122,111 & 46.0 & 265,601 & 100 \\
\hline Rural & 374,265 & 33.5 & 56,040 & 5.0 & 64,214 & 5.7 & 621,957 & 55.7 & $1,116,476$ & 100 \\
\hline $0-8$ & 213,760 & 35.0 & 19,218 & 3.1 & 33,864 & 5.5 & 344,081 & 56.3 & 610,923 & 100 \\
\hline $9-12$ & 138,728 & 32.1 & 27,866 & 6.4 & 22,578 & 5.2 & 243,608 & 56.3 & 432,780 & 100 \\
\hline $13+$ & 21,777 & 29.9 & 8,956 & 12.3 & 7,772 & 10.7 & 34,268 & 47.1 & 72,773 & 100 \\
\hline
\end{tabular}

and schools where $59 \%, 35 \%$ and $38 \%$ of the population reported to be exposed to cigarette smoke, respectively. More than $86 \%$ of restaurant-goers reported an exposure to secondhand smoke.

\section{Exposure to Advertising}

Over $92 \%$ of the survey participants reported being exposed to some cigarette advertising within the last 12 months. Consumers have primarily noticed cigarette advertising communicated by outdoor print media, as $75 \%$ of the respondents saw cigarette advertising on posters, billboards, or on public transportation vehicles. The second most common place for people to be exposed to cigarette advertising is the retail environment, and electronic media (TV and radio) occupy the third place. About $17 \%$ of respondents also saw cigarette advertising in print media (newspaper and magazines). Few were exposed to cigarette advertising on the internet and in movie theaters, but this low level of exposure may be due to a low frequency of theater visits and limited time spent searching the Web. Exposure to cigarette advertising in urban areas is higher than rural areas for all types of advertising media.

\section{Cigarette Brands and their Prices}

The Albanian cigarette market consists mostly of imported brands. Only two locally produced brands are reported by the smokers: Durres Special and Veve Lights. The most popular brand is Karelia Slims, with one-third of smokers reporting that this was the last brand they purchased before the survey. The second, third and fourth most popular are U.S. brands Winston Lights, Marlboro Lights, and LM Lights, suggesting that consumers in Albania are seeking the "light” versions of cigarettes. The survey information could not determine whether these choices are motivated by taste or by concerns about the health impact of tobacco use.

Based on the self-reported cigarette prices and brands, the weighted average price for a pack of cigarettes at the time of the survey was 125 lek, or \$1.29 USD. Over half of the smokers purchased cigarettes at a price of 120 lek, and 82\% of smokers smoked cigarettes that cost between 100 and 150 Lek. Cigarettes cheaper than 100 Lek are consumed by only $5 \%$ of smokers, and cigarettes costing more than 150 lek are purchased by 13\% of smokers.

\section{DISCUSSION}

Our survey confirmed the extremely high male smoking prevalence in Albania, with more than $64 \%$ of men aged 18 and over who smoke. Female smoking prevalence is lower compared to male, with about $19 \%$ of women aged 18 and over reporting to consume cigarettes, either regularly or occasionally. Comparing our estimates for 25-year-olds and above (66\% and $20 \%$ smoking prevalence for males and females in this age category, respectively) with the 1990 survey, we can conclude that smoking prevalence has increased over the last 17 years among both genders with a particularly large increase among females, more than doubling their smoking rate. The highest level of female smoking has been detected among young women living in urban areas - about one-third of women aged 20 to 24 living in towns reported they smoke. Our survey also found smoking prevalence higher compared to the more recent 2001 survey and suggest further increase in smoking rates in the 2000s, but one needs to be careful with such comparisons, due to differences in methodology and population segments included in the surveys.

However, the high smoking rates among youth suggest that smoking rates can be expected to increase in the future if tough tobacco control policies are not implemented. With higher rates of smoking among urban dwellers, the migration of women to the city is also likely to result in higher smoking prevalence among women. Given the role of women as mothers, there is a danger of a spill-over effect on the future generations of Albanian youth.

The level of education is positively related to smoking prevalence. This is the reverse of the situation in high-income countries, where the level of awareness of the harm associated with smoking is generally higher (11). A similar positive relationship between the level of education and smoking prevalence, however, has been detected in some former socialist economies in Central and Eastern Europe (11). Nevertheless, higher levels of education in 
Albania are associated with higher quit rates, as well as a higher likelihood of being an occasional smoker.

About $85 \%$ of current smokers smoke daily and with high intensity (males smoke 24 cigarettes per day and females smoke 14 cigarettes per day). Even countries notorious for high levels of tobacco use, such as Russia or Ukraine, do not report such a high intensity of cigarette use. Russian male smokers, for example, consume on average about 16 cigarettes per day, while females smoke on average 11 cigarettes per day (12). Since the risk for many smoking-attributable diseases increases in proportion to the number of cigarettes consumed [e.g., mortality from lung cancer is 25 times as high in heavy smokers than in never-smokers (13)], the public health and economic burden of smoking in Albania is likely to be high.

The survey detected very little use of other tobacco products. This is surprising, given that the 2003 GYTS survey found that about $10 \%$ of high school students consumed tobacco products other than cigarettes (14). A future survey should clarify this discrepancy.

The relatively small share of quitters in the population implies that tobacco control measures are inadequate. In high-income countries, ex-smoker rates have increased over the past three decades, with about $30 \%$ of the male population being former smokers (15). In contrast, only $7 \%$ of the Albanian population consists of former smokers. Nevertheless, there seems to be a demand for smoking cessation, as $27 \%$ of regular smokers reported not using tobacco for at least 24 hours in an attempt to quit. Quit attempts are more frequent in urban areas. Since the tobacco control policies adopted in 2007 are mostly affecting urban areas, quit rates should increase, particularly among the urban population, if sufficiently enforced. Engaging physicians in communicating the dangers of smoking and providing advice on effective means of quitting may further increase quit rates, as the survey indicates that doctors are only marginally active in providing this service to smokers.

Exposure to cigarette advertising, as measured before the implementation of the new tobacco policies in May 2007, had been widespread, with over $90 \%$ of the population exposed to cigarette advertising within the last 12 months before the survey. The urban population reported a higher level of exposure compared to people living in rural areas. Outdoor advertising, including billboards banned by the 2007 law, was the most frequently noticed advertising medium. However, exposure to advertising in the retail environment, television, radio, newspapers, and magazines was also found, despite the fact that these forms of advertising were illegal at the time, suggesting the need for better enforcement.

Our results reveal a high exposure to secondhand smoke prior to the implementation of the 2007 clean air laws. We are not aware of any estimates of the impact of secondhand smoke on public health in Albania, but evidence from other countries suggests that the public health burden of passive smoking amounts to about $15 \%$ of that of active smoking (16). Assuming that the mortality attributed to active smoking is about 3,300 persons per year in Albania (17), there are about 500 persons dying every year in Albania as the result of secondhand smoke, bringing the total death toll of tobacco use to 3,800 persons a year, about one-fifth of all yearly deaths (18). Although clean air laws are now in place, they need to be strictly enforced in order to achieve a substantial reduction in secondhand smoke exposure. In addition, the restriction on smoking may need to be broadened to include worksites, and the dangers of secondhand smoke need to be widely publicized, to further lower the high level of exposure to secondhand smoke.

Combining the results of our survey with respect to smoking prevalence and smoking intensity and using the latest available estimate of the adult population size [1,985,665 in 2000 (19)], we estimate that 1.394 billion cigarettes (about 1,394 metric tons) were consumed in Albania in the first quarter of 2007. ${ }^{1}$ Assuming that cigarette consumption is proportionately distributed across all four quarters, the 2007 consumption of cigarettes in Albania would have been about 5.576 billion cigarettes. This suggests an annual per capita consumption of 2,808 cigarettes. The ERS estimated a consumption of 2,150 cigarettes per year in 1999. If consumption increased by $75 \%$ from 2000 to 2006, as reported by the Ministry of Health, this would imply a per capita cigarette consumption exceeding 3,700 in 2007. On the other hand, the Ministry of Health estimates that cigarette consumption in 2006 reached about 1,841 cigarettes per capita. Our estimate is about half-way between these two extreme points. Given that the prevalence data has been verified by several studies, future studies should pay attention to estimates of smoking intensity, in order to better establish the actual consumption of cigarettes in Albania.

Using our estimate of the total consumption of cigarettes in Albania of 278.8 million packs and the average price per pack of 125 lek, we calculate that Albanian households spent 34.85 billion lek (\$358.6 million USD) ${ }^{2}$ on cigarettes in 2007. That represents 17,551 lek (\$181 USD) per capita, or $5.8 \%$ of GDP per capita in 2007. ${ }^{3}$ Since there are about 822,000 smokers in Albania (41.4\% of the population over 18 years of age), a smoker spends on average 42,396 lek (\$436 USD) per year on cigarettes, the value of about two months of the average wage (the average monthly wage in 2006 was about 23,000 lek per month ${ }^{4}$ ).

Substantial evidence from many countries demonstrates that a very potent policy for reducing smoking prevalence is high cigarette prices that can be achieved by higher tobacco taxes (20). Cigarette taxes are low in Albania (the average excise tax per pack of cigarettes is about $\$ 0.42$ USD) (21), representing only about $33 \%$ of the average retail price (\$1.29 USD). Since both the World Bank and WHO recommend that the tobacco tax constitute at least $67 \%$ of the retail price, there is room for a sizable tax increase in Albania. Such an increase would not only reduce the high smoking prevalence and smoking intensity associated with a large economic loss and public health burden, it would also generate additional resources for the government in the form of tobacco taxes.

In summary, our results suggest that smoking is a major problem among Albanian men, and is becoming an increasingly greater

\footnotetext{
${ }^{1} 1,985,665 * 34.9 \% * 21.9$ cigarettes/day *90 days $+1,985,665 * 6.5 \% * 16.7$ cigarettes/week*12.9 weeks.

${ }^{2}$ This estimate is close to the estimate of 300 million Euro reported by the Eastern European Times, June 19, 2007: “Smoke in public? Not in Albania,” by Jonilda Koci.

${ }^{3}$ Expected GDP per capita in 2007 was \$3,100 USD.

${ }^{4}$ Personal communication with Milva Ekonomi, the director of the Agenda Institute in Albania.
} 
Appendix 1. The post-stratification weight

\begin{tabular}{|c|c|c|c|c|c|}
\hline \multirow[b]{2}{*}{ Age group and sex } & \multicolumn{2}{|c|}{ Census 2001} & \multicolumn{2}{|c|}{ AAT Survey } & \multirow[b]{2}{*}{$\begin{array}{l}\text { Post-stratification } \\
\text { weight }\end{array}$} \\
\hline & Population & $\begin{array}{l}\text { Proportion } \\
\text { of population }\end{array}$ & Population & $\begin{array}{l}\text { Proportion } \\
\text { of population }\end{array}$ & \\
\hline Age 18-19: Male & 53,353 & 2.7 & 110 & 2.8 & 0.9770576 \\
\hline Age 18-19: Female & 57,161 & 2.9 & 90 & 2.3 & 1.2794146 \\
\hline Age 20-24: Male & 111,143 & 5.6 & 238 & 6.0 & 0.9407174 \\
\hline Age 20-24: Female & 120,969 & 6.1 & 210 & 5.3 & 1.1604029 \\
\hline Age 25-34: Male & 206,484 & 10.4 & 354 & 8.9 & 1.1749981 \\
\hline Age 25-34: Female & 222,771 & 11.2 & 341 & 8.5 & 1.3160073 \\
\hline Age 35-44: Male & 217,217 & 10.9 & 413 & 10.3 & 1.0594922 \\
\hline Age 35-44: Female & 217,118 & 10.9 & 424 & 10.6 & 1.0315350 \\
\hline Age 45-54: Male & 161,609 & 8.1 & 555 & 13.9 & 0.5865791 \\
\hline Age 45-54: Female & 153,073 & 7.7 & 466 & 11.7 & 0.6617085 \\
\hline Age 55-64: Male & 119,613 & 6.0 & 354 & 8.9 & 0.6806583 \\
\hline Age 55-64: Female & 113,791 & 5.7 & 191 & 4.8 & 1.2001307 \\
\hline Age 65+: Male & 108,101 & 5.4 & 160 & 4.0 & 1.3610176 \\
\hline Age 65+ : Female & 123,262 & 6.2 & 94 & 2.4 & 2.6415289 \\
\hline Total & $1,985,665$ & 100.0 & 4000 & 100.0 & \\
\hline
\end{tabular}

concern among women. The study proposes some important measures that can be taken to reduce smoking rates, including raising taxes on cigarettes, promoting cessation particularly via the health care system, and executing stricter clean indoor air laws. Implementing and enforcing these policies would reduce the current smoking rates as well as future smoking prevalence by discouraging youth from smoking.

\section{REFERENCES}

1. U.S. Department of Health and Human Services. Reducing the health consequences of smoking: 25 years of progress. A report of the Surgeon General. DHHS publication no. (CDC) 89-8411. Rockville: U.S. Department of Health and Human Services, Public Health Service, Centers for Disease Control and Prevention, Center for Chronic Disease Prevention and Health Promotion, Office on Smoking and Health; 1989.

2. U.S. Department of Health and Human Services. The health benefits of smoking cessation: a report of the Surgeon General. DHHS publication no. (CDC) 90-8416. Rockville: U.S. Department of Health and Human Services, Public Health Service, Centers for Disease Control and Prevention, Center for Chronic Disease Prevention and Health Promotion, Office on Smoking and Health; 1990.

3. Yang G, Fan L, Tan J, Qi G, Zhang Y, Samet JM, et al. Smoking in China: findings of the 1996 National Prevalence Survey. JAMA. 1999 Oct 6;282(13):1247-53.

4. Anderson Johnson C, Palmer PH, Chou CP, Pang Z, Zhou D, Dong L, et al. Tobacco use among youth and adults in Mainland China: the China Seven Cities Study. Public Health. 2006 Dec;120(12):1156-69.

5. Jenkins CN, Dai PX, Ngoc DH, Kinh HV, Hoang TT, Bales S, et al. Tobacco use in Vietnam. Prevalence, predictors, and the role of the transnational tobacco corporations. JAMA. 1997 Jun 4;277(21):1726-31.

6. World Health Organization [homepage on the Internet]. Cross country profile [cited 2008 Feb 26]. Available from: http://data.euro.who.int/tobacco/Default.aspx?TabID=2444

7. The World Bank [homepage on the Internet]. Albania health sector note. Report No. 32612-AL. February 2006 [cited 2008 Feb 26]. Available from: http://www-wds.worldbank.org/external/default/WDSContentServer/WDSP/ IB/2006/04/26/000160016_20060426172842/Rendered/PDF/32612.pdf.

8. Shafey O, Dolwick S, Guindon GE, editors. Tobacco control: country profiles. 2nd ed. Atlanta: American Cancer Society; 2003.
9. Shapo L, Gilmore AB, Coker R, McKee M, Shapo E. Prevalence and determinants of smoking in Tirana city, Albania: a population-based survey. Public Health. 2003 Jul;117(4):228-36.

10. Shuperka R. Living Standard Measurement Survey (LSMS). Tirana: World Bank Institute of Public Health Research; 2000.

11. Bobak M, Jha P, Nguyen S, Jarvis M. Poverty and smoking. In: Jha P, Chaloupka FJ, editors. Tobacco control in developing countries. Oxford: Oxford University Press; 2000. p. 41-61.

12. Europe and Central Asia Human Development Department the World Bank. Dying too young: addressing premature mortality and ill health due to non-communicable diseases and injuries in the Russian Federation. Washington,D.C.: The World Bank; 2005.

13. Doll R, Peto R, Boreham J, Sutherland I. Mortality in relation to smoking: 50 years' observations on male British doctors. BMJ. 2004 Jun 26;328(7455):1519.

14. Centers for Disease Control and Prevention [homepage on the Internet]. Smoking \& Tobacco Use: Global Youth Tobacco Survey (GYTS). Albania Fact Sheet [cited 2008 Jun 20]. Available from: http://www.cdc. gov/tobacco/global/GYTS/factsheets/euro/2003/albania factsheet.htm.

15. Gajalashmi CK, Jha P, Ranson K, Nguyen S. Global patterns of smoking and smoking-attributable mortality. In: Jha P, Chaloupka FJ, editors. Tobacco control in developing countries. Oxford: Oxford University Press; 2000. p. 11-39.

16. Gan Q, Smith K, Hammond S, Hu TW. Disease burden from smoking and passive smoking in China. In: Hu TW, editor. Tobacco Control Policy analysis in China: economics and health. Singapore: World Scientific Publishing; 2007.

17. The Association "For a Tobacco Free Albania". The Framework Convention on Tobacco Control and the implementation of the anti-tobacco law in Albania. Tirana: 2007.

18. The World Bank. World development indicators 2007. Washington,D.C.: The World Bank; 2007.

19. Institute of Statistics [homepage on the Internet]. Resident population by group of age, place of residence at 1 April 2000 and sex [cited 2008 Jun 20]. Available from: www.instat.gov.al/repoba/Rezultate_linqe/Tabelat_Web/Kapitulli2/tab_2.18.xls.

20. Ross H, Chaloupka FJ. Economic policies for tobacco control in developing countries. Salud Publica Mex. 2006;48 Suppl 1:S113-20.

21. Ministry of Finance of Republic of Albania [homepage on the Internet]. The main taxes in the Albanian tax system [cited 2008 Jun 20]. Available from: http://www.minfin.gov.al.

Received February 26, 2008 Accepted June 23, 2008 